
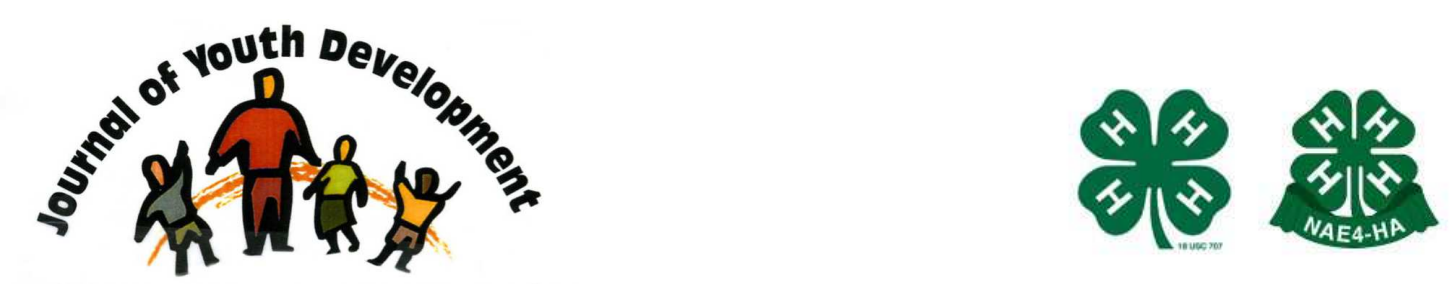

Bridging Research \& Practice

\title{
Environmental Service and Outdoor Adventure as a Context for Positive Youth Development: An Evaluation of the Crow River Trail Guards Program
}

\author{
Julie Ernst \\ Environmental Education Program \\ University of Minnesota Duluth \\ Duluth, MN \\ jernst@d.umn.edu \\ Jessamy Schwartz \\ Environmental Education Program \\ University of Minnesota Duluth \\ Duluth, MN \\ schwa918@d.umn.edu
}




\title{
JOURNAL OF YOUTH DEVELOPMENT \\ bridging research and practice

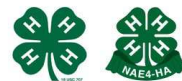

\section{Environmental Service and Outdoor Adventure as a Context for Positive Youth Development: An Evaluation of the Crow River Trail Guards Program}

\author{
Julie Ernst and Jessamy Schwartz \\ University of Minnesota Duluth
}

\begin{abstract}
Trail Guards, a community-based organization in Minnesota, offers youth the opportunity to participate in park/trail maintenance and enhancement projects. Through these environmental service projects, Trail Guards seeks to foster the following developmental outcomes in youth participants: selfawareness of skills and strengths; self-worth; personal and social self-efficacy; sense of belonging and acceptance; team work and cooperation skills; and a sense of community responsibility. Trail Guards ultimately aims for youth to transfer these skills and socially appropriate behaviors to settings and activities beyond Trail Guards and to participate in the community in other positive ways. A program evaluation indicated Trail Guards seems to be achieving these youth development outcomes, and that the success of the program may be attributed to the program leader serving as a positive adult role model and providing a safe and caring environment, as well as to community involvement. Implications are discussed.
\end{abstract}

\section{Introduction}

Crow River Trail Guards is a non-profit, community-based organization in Paynesville, Minnesota that aims to promote environmental and personal awareness through outdoor challenge, educational opportunities, and environmental service for Paynesville youth. They also seek to ensure the Crow River Nature Park and Trail is conserved for the environmental and recreational benefit of the Paynesville community. Crow River Trail Guards evolved out of Minnesota's "Clean the River" program during the late 1980s and early 1990s. When the city, at the prompting of local resident and now program director, designated a 12-acre parcel of river bottom land to be a city park and trail head for a future trail system, adult and youth volunteers became involved in clearing trails and constructing a stairway and footbridge. Youth 
continued to be drawn to this area and were soon put to work as "guards" of the trail, educating users of the trail and protecting the new trail system from vandalism.

Currently, Trail Guards offers youth ages 9-19 the opportunity to participate in park/trail maintenance and enhancement projects, as well as educational presentations, nutritional snacks, and team-building games. These activities take place from April to October every Saturday morning. The Trail Guards participants receive points for attendance on Saturday mornings, which can then be used as a reward to participate in outdoor adventure trips such as local adventure day trips and overnight canoe, backpacking, and bike trips. Through these Saturday morning environmental service projects and outdoor adventure experiences, Trail Guards seeks to foster the following developmental outcomes in youth participants: selfawareness of skills and strengths; self-worth; personal and social self-efficacy; sense of belonging and acceptance; team work and cooperation skills; and a sense of community responsibility. Trail Guards ultimately aims for youth to transfer these skills and socially appropriate behaviors to settings and activities beyond Trail Guards and to participate in the community in other positive ways.

The philosophical underpinnings of Trail Guards closely align with what has been identified in the youth development research literature as key supports and opportunities: caring relationships with adults and peers, emotional and physical safety, a connection with the community, opportunities for meaningful involvement and participation, and opportunities to participate in challenging and engaging activities and learning experiences (Gambone, Klem, Connell, 2002). Further, there is some research within the environmental education literature to suggest the effectiveness of environmental action in promoting youth's physical, intellectual, psychological, and social well-being. Several studies of environmental action programs indicate that these programs provide youth opportunities for meaningful community contributions that foster outcomes such as self-confidence, citizenship competence, cooperation skills, selfefficacy, and an understanding of diverse viewpoints (Ernst, 2005; Melchior, \& Bailis, 2004; Volk, \& Cheak, 2003).

Research by Schusler and Krasny (2010) yielded nine strategies for facilitation of youth development outcomes through environmental action: creating safe spaces; providing structure; building relationships; bridging differences; setting expectations; providing opportunities for meaningful contribution; supporting youth; connecting youth with community; and expanding horizons. These strategies are also well-aligned with the philosophical underpinnings of Trail Guards and implementation of activities.

Trail Guards provides a safe and respectful social environment, coupled with the "calming environment of green space" (Schusler, \& Krasny, 2010, p. 219). Team-building games, outdoor recreation, shared meals/snacks, and simply having fun together are used to build trusting relationships among youth participants and adult volunteers. Trail Guards brings together diverse youth and community members who normally would not interact and allows for all youth to contribute to the project at hand. Through their on-going maintenance and stewardship of their park and trail, youth see their contributions making a real difference and see their community valuing and enjoying their efforts. Through their service, youth earn points that can be redeemed for day and overnight outdoor adventure trips, which expand the horizons of youth through novel outdoor adventure experiences.

Trail Guards, however, does not require youth to "work" during the Saturday morning activities; if youth choose not to do any work, they do not earn points, but they are still welcome to 
attend. Thus, Trail Guards does not emphasize clear, rigorous expectations in the sense of physical work, but they do have expectations regarding behavioral expectations and respect for each other. Trail Guards also does not use a structure for involving youth in decision-making/ goal-setting, nor incorporating youth into leadership roles, which is contrary to Schusler and Krasny's suggestion for shared decision-making, encouraging youth ownership, and providing nested leadership opportunities (2010, p. 219).

\section{Evaluation Methodology}

\section{Purpose and Questions}

The evaluation purpose was to determine if the learning-level outcomes of the Trail Guards program were being achieved, as well as to identify other unintended program outcomes. The intended users of this evaluation were the Crow River Trail Guards Executive Director and Board of Directors, in their efforts to share program outcomes with and encourage support from current and future funders, as well as to identify new potential funders. There were two questions guiding the evaluation:

1. Does participation in the Crow River Trail Guards program result in the following outcomes among youth participants: self-awareness of participants' own skills and strengths; self-worth; personal and social self-efficacy; sense of belong and acceptance; team work and cooperation; and sense of community responsibility?

2. What other program outcomes (unintended outcomes) are being achieved?

\section{Evaluation Instruments}

Several data collection instruments were needed to address the evaluation questions and the specific needs of the evaluation users. Instruments were developed based on the evaluation questions, resources available, the intended uses for the evaluation, and the desire to minimize additional layers of student assessment. The use of a questionnaire for past participants was to address the concern that many evaluations of youth development programs measure outcomes at the end of program delivery without follow-up measurement (Catalano, Berglund, Ryan, Lonczak, \& Hawkins, 2004).

- Past Participant and Parent Questionnaire: These two questionnaires used a combination of closed- and open-ended items to address the intended and unintended program outcomes. (See appendix.)

- Current Participant Self-Report. The self-report was developed to be used in a pretestposttest treatment group-only design. (See appendix.) Sections addressed the intended outcomes of self-awareness, self-worth, personal and social self-efficacy, sense of belonging, cooperation and teamwork, and sense of community responsibility. These items were developed based on the definition of these items and/or modified from items found within the online database, the Compendium for Assessment and Research Tools for Measuring Education and Youth Development Outcomes (www.cart.rmcdenver.com).

- Focus Group Question Guides for Past Participant, Parents, and Community Members. A question guide was developed to address the evaluation questions, with questions aimed toward the particular audiences. Prior to the focus groups, questions were pilot tested for clarity and fit with evaluation and audience. 


\section{Data Collection Procedures.}

Permission to conduct the evaluation was sought from the University of Minnesota's Institutional Review Board, who determined the evaluative purpose of this study did not fall within their definition of research; thus, their approval was not required for this evaluation. Questionnaires were mailed to past participants and parents of current participants in April 2012. The questionnaire was accompanied by a Subway Restaurant gift card in the amount of $\$ 5$, as well as an invitation letter explaining the purpose of the evaluation and other consent-like information. Past participants received their questionnaire at their parent's or guardian's mailing address, with the envelope addressed to the parent/guardian. This approach was used to make parents aware of the data collection, even though consent was not required through Institutional Review Board guidelines. A post card reminder was sent out a few days after the questionnaire was mailed to encourage responses. Of the 58 questionnaires mailed to past participants, 21 of them were returned for a response rate of $36.2 \%$. Of the 54 questionnaires mailed to parents of current participants, 20 were returned $37.04 \%$.

Focus groups were conducted at a local pizzeria in the town of Paynesville, MN in April 2012. There were three focus groups: past participants, parents of participants, and community members. Purposeful sampling techniques were used to identify those who would participate in the various focus groups, through the assistance of the Executive Director. The intent was to invite 6-8 individuals for each group who were considered "information rich" in terms of their knowledge and experience with the program. One participant attended for the past participant focus group, four participated in the parent focus group and six participated in the committee member focus group. Based on conversations with the Executive Director and observations from the focus group interviewers, the attendance reflected scheduling difficulty, as opposed to lack of interest in participating.

The current participant self-report was administered as a pretest in late April 2012, at the first Saturday morning work day for the season. All current participants were invited to participate. Twenty-seven pretests were administered. Posttests were administered at the end of the season (October 2012), with students taking the posttest on the last work day if possible, and those not present at that final work day receiving the posttest by mail. Thirteen posttests were returned, however only nine of those were able to be matched with a pretest. Thus, the response rate for the self-report was nine current participants.

\section{Evaluation Results}

\section{Quantitative Results}

- Self-Awareness of Personal Skills and Strengths: Past participants were asked to rank their level of agreement with their confidence in their ability to identify their personal skills and strengths. They agreed that participation in Trail Guards increased their selfawareness $(M=3.92, S D=.91)$. Parents also agreed that participation increased their child's self-awareness of their skills and strengths, as their average response across two items was $4.05(\mathrm{SD}=.58)$. For the three items addressing self-awareness, current participants' scores indicated perhaps a slight increase from pretest to posttest ( $\mathrm{M}=$ $4.19, \mathrm{SD}=.69$ and $M=4.30, \mathrm{SD}=.48$ ). Collectively, these responses suggest Trail Guards may be helping youth develop a sense of their own personal skills and strengths.

- Self-Worth: Past participants indicated their self-worth through their level of agreement with feeling that others truly appreciate them for who they are and that they feel they have made a valuable contribution to the work of Trail Guards. Past participants agreed 
that participation in Trail Guards had led to feelings of self-worth $(M=3.98, S D=.64)$. Parents responded similarly, generally agreeing that Trail Guards led to feelings of selfworth in their child $(M=3.95, S D=.62)$. Current participants were asked if they felt others respected and appreciated them for who they are, if they felt worthy of being respected, and if they felt valued as a person. Feelings of self-worth increased slightly from pretest to posttest scored $(M=4.00, S D=.62$ and $M=4.20, S D=.54$ respectively). Collectively this suggests Trail Guards may be effective in helping increase youth's feelings of self-worth.

- Personal and Social Self-Efficacy: Past participants were asked to rank their agreement with statements about their belief in having developed a greater ability to accomplish tasks and gaining a greater ability to participate in meaningful relationships with other people. On average, participants agreed with these statements $(M=4.15, S D=.65)$. Parents responded similarly, generally agreeing that participation helped their child develop personal self-efficacy as well-as social self-efficacy $(M=4.10, S D=.55$ and $M$ $=3.90, \mathrm{SD}=.60$ respectively). To measure personal self-efficacy, current participants were asked to rate their level of agreement with feeling like they can accomplish a task that is given to them and were asked the degree to which Trail Guards helped this. Their social self-efficacy was assessed by asking for their level of agreement with knowing how to act and what to say when they are with others, as well as knowing how to get along with others. Across these five items, participants' scores increased slightly from pretest $(M=4.22, S D=.57)$ to posttest $(M=4.44, S D=.39)$. Collectively, these responses suggest participation in Trail Guards may be increasing personal and social self-efficacy in youth participants.

- Sense of Belonging and Acceptance: Past participants were asked the extent to which they felt they were accepted as a member of Trail Guards and if they felt they developed a sense of belong through participation in Trail Guards. Their responses across the two items indicated agreement $(M=4.02, S D=.76)$. Due to an error in the parent questionnaire, parents were not asked through a close-ended item to respond to sense of belonging and acceptance being developed through Trail Guards Participation. Current participants responded to two items: if Trail Guards helped them feel accepted and that others accepted them for who they were, as well as if they felt like a part of the group. Participants' sense of belonging and acceptance increased from a pretest average of $3.89(\mathrm{SD}=.65)$ to a posttest average $4.23(\mathrm{SD}=.47)$ on the posttest. As noted with the prior outcomes, these results suggest Trail Guards may be fostering a sense of belonging and acceptance among its youth participants.

- Teamwork and Cooperation: Past participants agreed that Trail Guards helped them learn to cooperate with others and how to work with others toward a common goal (M $=4.33, \mathrm{SD}=.54)$. Parents also agreed, with an average response of $4.25, \mathrm{SD}=.57$ across the two items. Current participations were asked about teamwork and cooperation through their level of agreement with knowing how to work with others to accomplish a task and cooperating with others to get a job done, even if they don't particularly like who they are working with. They also were asked if they agree that Trail Guards helped them to learn to work as a team and cooperate with others. Across these three items, participants had an average of $4.07(\mathrm{SD}=.49)$ on the pre-test and an average of $4.52(S D=.41)$, suggesting an increase in teamwork and cooperation skills. Collectively, these results lend support to stating the positive influence of Trail Guards on youth's skills in teamwork and cooperation. 
- Sense of Community/Civic Responsibility: Past participants were asked their level of agreement with feeling that they play an important role in the community and if they are a more responsible community because of their participation in Trail Guards. Past participants agreed $(M=4.02 ; S D=.56)$ with these statements. Parents gave their level of agreement to statements about their child feeling valued by the community for his or her contributions, having a positive attitude toward contributing to the community and having a sense of responsibility towards the Paynesville Community. Parents also agreed that their child has a sense of community and civic responsibility because of participation in Trail Guards, with an average rating across the two items of 3.9 (SD = .70). Current participants responded to five items regarding sense of community responsibility. They were asked their level of agreement with statements about making a difference in their community, their responsibility to make their community better, how important they felt it was to contribute to their community, and if they plan to volunteer in the community throughout their life. Current participants scored $4.13(S D=.69)$ on the pretest and this score rose to $4.44(\mathrm{SD}=.49)$ on the posttest. Collectively, these results suggest Trail Guards seems to be influencing youths' sense of community and civic responsibility.

\section{Qualitative Analysis and Results}

Qualitative data was collected through the open-ended responses on the questionnaires, as well as through the focus groups. Of those questionnaires that were returned, eight past participants and three parents contributed to open-ended responses. These responses were integrated into the qualitative data from the focus groups.

The focus group recordings were transcribed into meaningful phrases and organized according to interview question. The transcription was reviewed several times to obtain a general sense of reoccurring themes. Once primary themes were established and given codes, phrases were analyzed according to these themes and assigned these codes. Once the data was separated into the primary themes, the researcher examined the data by theme to search for any emerging sub-themes. This process was not linear and the analyst frequently went back and forth between the raw data and the themes to verify the accuracy of the themes as well as the placement of the data within these themes (Patton, 2002). After coding was completed with the focus group data, the open-ended questions were reviewed, coded with the previously established primary themes and sub-themes, and combined with focus group data. All questionnaire data fit under these established themes so no new themes or sub-themes were added during this process.

The results of the qualitative data are presented below according to primary theme and its correlating emergent sub-themes.

\section{Themes Relating to Program Outcomes}

\section{Personal Growth}

The primary theme of personal growth was used to code participant responses regarding outcomes that described participants' development of self as a result of the Trail Guards program. The sub-themes sense of belonging, commitment, interpersonal skills, and self-worth all emerged from this theme.

\section{Sense of Belonging}

The sub-theme sense of belonging was described as feelings of comfort related to the social environment created by Trail Guards. 
- "What I have seen is that there is a great loyalty to Trail Guards. What I have seen is that there is a great loyalty to Trail Guards. It's like a family because a lot of those kids don't have a loyalty to anything." - Community Member

- "This is a real home for them." - Community Member

A sense of belonging was apparent through community member responses who pointed out that Trail Guards seemed like a "family" and a "home" to some participants. Past participants support this sense of belong in explaining that participants go because they want to and that some look forward every week to participating in the Saturday morning "rituals."

\section{Commitment/Loyalty}

The sub-theme commitment emerged as phrases that described feelings or actions of devotion or attachment to Trail Guards.

- $\quad$ "He started when he was old enough to start, which is eight, six or eight years ago. And he's sixteen now, almost seventeen. So he's been in there for a while too. And he loves it." - Parent

- "They enjoy it. My Kids are out of bed every Saturday morning and away they go." Parent

Support for the outcome of commitment is shown through discussions about how many years the kids participate in Trail Guards (which was anywhere from seven to 11 years) and how motivated participants seem to be to take part in the activities even if it means getting up early on Saturday mornings or going out in the rain.

\section{Interpersonal Skills}

The sub-theme of interpersonal skills described the skills that the kids learn through Trail Guards that help them to communicate and work with other people.

- "...we are all different but can still work together towards a same goal." - Past Participant

- "You're going to have to work with somebody. Like you might not know them or you might not like them, but you still have to get the job done." - Past Participant

Interpersonal skills were apparent through examples of how participants have to use teamwork, cooperation, and communication to complete tasks. Further, one past participant stated that being in Trail Guards helped him or her to become more outgoing and open up to other people.

\section{Self-worth}

The sub-theme of self-worth emerged from data that described participants feeling acknowledged and appreciated for who they are through participation in Trail Guards.

- "I made a difference; I learned what tiny things someone does can change something bigger." - Past Participant

- "Yeah, I'm just a person, but actually I can help somebody else." - Past Participant

Past participants explained that Trail Guards gave them the opportunity to challenge themselves, try new things, and meet new people. Parents reported seeing their children open 
up and become less shy as a result of Trail Guards. Community members noticed participants sharing their experiences and showing pride in what they had accomplished.

\section{Other Personal Growth Outcomes}

Other personal growth outcomes did not fit into the other subthemes but were important to note. The quotations below described some of the outcomes gained through participation in Trail Guards and, even though some where only mentioned once, speak to the wide range of possible personal growth opportunities through participation in Trail Guards.

- $\quad$ "For any high school kid to devote themselves to work, it helps them develop that goal setting." - Community Member

- "[Trail Guards helps youth develop] A sense of responsibility and accountability." Community Member

- "They are more than willing to listen to the adults. I am sure that is a carryover from the Trail Guards." - Community Member

Other outcomes from Trail Guards participation that emerged from this data were obtaining job skills, gaining independence, and feeling satisfaction from completing tasks. Further, participants gained new perspectives of different cultures (through participation on field trips) as well as becoming aware of the differences in socio-economic statuses in their own community.

\section{Benefit to the Community}

The second overarching theme that emerged from the data was benefit to the community. This theme included any qualitative data that described how participation in Trail Guards helped kids have a positive impact on the community and how the work they did on the trails was a benefit to the community of Paynesville. The sub-themes quality citizens and park use emerged from this primary theme.

\section{Quality Citizens}

The sub-theme of quality citizens describes the impact that Trail Guards has on the participants and how this positively contributed to the community of Paynesville.

- "I think it's a huge piece on why our school climate is as empathetic towards each other's gifts as well as deficits." - Community Member

- $\quad$ "If I wouldn'tve started going trail guards I probably would've gotten myself into trouble." - Past Participant

Past participants and community members attribute Trail Guards with keeping kids "out of trouble." Specifically, one community member explained that participating in Trail Guards helps kids to become responsible, graduate from school, and acquire jobs. Parents and community members also suggested that Trail Guards has created an inclusive community where kids treat each other with respect.

\section{Park Use}

The nature trail that participants build and maintain has been beneficial to the community and phrases associated with this description were coded with the sub-theme of park use. 
- "And I enjoy the trail personally. It sounds like it didn't used to be so nice. I have only heard stories about what used to happen down by the river because it didn't used to be a nice place." - Community Member

- "...it's seen as a big asset now. They talk about that. With the glacial lakes trail there has been discussion about getting the trail closer to that trail. It's definitely a plus. It's a very positive thing. It's good it's been growing." - Community Member

Parents explained how the park has been used for graduation pictures and walking dogs. In addition, participants in the Trail Guards program have put on a Moonlight Meander program for the community. Community members also see the park as a big asset to the community, especially because of the transformation it took many years ago from being just a place where people threw garbage to becoming a frequently-used nature park.

\section{Themes Relating to Reasons for Program Success}

\section{Program Leader}

Some qualitative data diverged from program outcomes and described what may have contributed to the success of the Trail Guards program. One of the primary themes was Program Leader, which described the role the Trail Guards program leader has had in the program's success. Two sub-themes that emerged from this theme were safe environment and role model.

\section{Safe Environment}

One of the reasons why the Trail Guards program is successful may be because of the safe environment that the leader of Trail Guards provides. This sub-theme is best described by respondents through the following quotes:

- " "...he has created a loving, caring environment for kids." - Community Member

- "Like, I know I could drop them [my children] off there [Trail Guards] and pick them up and they'll be safe. So I don't gotta worry about them. You know. He keeps a good eye on them." - Past Participant

\section{Role Model}

The sub-theme role mode/ emerged through responses about the Trail Guards program leader and the positive impact he has had on the participants.

- "And he's such a positive person, he just brings out the good in people I think. And I mean he's kinda fun to be around I think, the kids enjoy being around him, he's just so positive." Parent

- "Oh, I think he is proud of these kids you know. In a way I think he feels like they're kinda his kids, and you know that he's helping raise them an you know in a way he is because they look up to him." -Parent

It is apparent that part of the success of Trail Guards has been a result the program leader providing a safe environment and being a good role model. This is evident by the several references made about the program leadership from the past participants, community members, and parents of participants. 


\section{Community Involvement}

Another theme that emerged that helped describe why the program may be successful was community involvement. This theme described how the community's support has played a significant role in the success of the Trail Guards program.

- $\quad$ "[I] have been called on a few times to come and talk to the kids about civic related questions, and give them support as to what a positive improvement they have made in the community and have helped out." - Community Member

- $\quad$ "It takes a community to raise our kids and the same show doesn't fit everybody. You need lots of different styles and sizes, you know." - Community Member

The community has contributed to the success of Trail Guards by providing expertise and guidance through Saturday morning talks. They also have helped out by volunteering for programs and volunteering help chaperone field trips.

\section{Discussion}

\section{Integration of Results}

Table 1 incorporates the quantitative data with the data collected through the focus groups and responses from the questionnaires' open-ended questions. In general, there was consistency across the quantitative and qualitative results, with qualitative data to support all of the intended outcomes. In addition, the qualitative findings yielded several unintended outcomes, including a general positive influence on youth behavior. 
Table 1

Integration of Quantitative and Qualitative Results

\begin{tabular}{|c|c|c|c|c|}
\hline Outcome & $\begin{array}{l}\text { Past } \\
\text { Participants } \\
\text { Mean (SD) }\end{array}$ & $\begin{array}{l}\text { Parents } \\
\text { Mean } \\
\text { (SD) }\end{array}$ & $\begin{array}{l}\text { Net Change for } \\
\text { Current } \\
\text { Participants in Pre- } \\
\text { Posttest Scores }\end{array}$ & $\begin{array}{l}\text { Qualitative to Support } \\
\text { Outcome }\end{array}$ \\
\hline Self-awareness & $3.92(.91)$ & $4.05(.58)$ & .11 & + \\
\hline Self-worth & $3.98(.64)$ & $3.95(.62)$ & .20 & + \\
\hline $\begin{array}{l}\text { Personal and social } \\
\text { self-efficacy }\end{array}$ & $4.15(.65)$ & $4.10(.55)$ & .22 & + (interpersonal skills) \\
\hline Sense of belonging & $4.02(.76)$ & -- & .34 & + \\
\hline $\begin{array}{l}\text { Teamwork and } \\
\text { cooperation skills }\end{array}$ & $4.33(.51)$ & $4.25(.57)$ & .45 & + \\
\hline $\begin{array}{l}\text { Sense of community } \\
\text { and civic responsibility }\end{array}$ & $4.02(.56)$ & $3.90(.70)$ & .31 & $\begin{array}{l}+ \text { (sense of responsibility and } \\
\text { accountability toward } \\
\text { community) }\end{array}$ \\
\hline $\begin{array}{l}\text { Feelings of } \\
\text { commitment/loyalty to } \\
\text { program }\end{array}$ & -- & -- & -- & + \\
\hline $\begin{array}{l}\text { Positive youth } \\
\text { behavior }\end{array}$ & -- & -- & -- & $\begin{array}{l}+ \text { (out of trouble, goal } \\
\text { setting, treating each other } \\
\text { and adults with respect, } \\
\text { listening to adults, motivation } \\
\text { to graduate and get a job) }\end{array}$ \\
\hline $\begin{array}{l}\text { Community recognition } \\
\text { of youths' contribution } \\
\text { to community }\end{array}$ & -- & -- & -- & $\begin{array}{l}+ \text { (community recognition of } \\
\text { recreational benefit to } \\
\text { community and benefit to } \\
\text { community from positive } \\
\text { youth behavior and youth } \\
\text { contribution) }\end{array}$ \\
\hline
\end{tabular}

\section{Reasons for Program Success}

While this was not the focus of the evaluation, nor something investigated in the quantitative portion of the evaluation, qualitative findings suggest these positive outcomes may, at least in part, be attributed to program leadership and community involvement in the program. There was strong and consistent qualitative data to suggest that the program leader served as a positive adult role model and provided a safe and caring environment, which seemed integral to youth's on-going participation and the positive outcomes that resulted from participation. There was also qualitative data to suggest that the community played a significant role in contributing to the program, and that this contribution was also integral to the program's success.

\section{Conclusion}

It is important to note several limitations, prior to offering a conclusion to this evaluation study. First, there is the potential for a nonresponse bias, with those responding representing perspectives of participants who like the program. Ideally, methods would have been used to contact non-respondents to ask about their nonresponse, to rule out this potential bias, but this was not done due to financial and time limitations. Another limitation relating to past participant respondents is in the sampling decisions that led us to focus on younger past participants, as these past participants were more likely to be living at home and thus still at the 
address in the program database. Responses from these past participants may be different from past participants who were in Trail Guards a longer number of years ago. Finally, this evaluation didn't control for program "dose," in the sense that the amount of time youth participate varies greatly (both in terms of the amount of time in one season and in the number of years overall). It would seem that the amount of participation would likely shape perceptions as to what was gained through participation. Due to the relatively small number of respondents, particularly in the pre-post self-report, it was not possible to control for prior participation, which may explain why scores on the pretest version of the self-report were quite high. This may have limited the amount of change the self-report was able to capture and consequently there may be more of a gain in these outcomes than reflected by these results.

In spite of these limitations, the consistency in results from across data collection instruments and information sources suggest Trail Guards is likely fostering the following outcomes among its youth participants: self-awareness of their own skills and strengths; self-worth; personal and social self-efficacy; sense of belong and acceptance; team work and cooperation; and sense of community/civic responsibility. In addition, participation may also be leading to the development of positive youth behavior, such as goal-setting, staying out of trouble, developing a sense of responsibility and accountability, and treating their peers and adults with respect.

The results from this evaluation suggest these outcomes are being achieved in part due to the program leader serving as a positive adult role model and providing a safe and caring environment. There was also qualitative data to suggest that the community played a significant role in contributing to the program, and that this contribution was also integral to the program's success. These findings are consistent with the key supports and opportunities identified in the youth development, specifically caring adult relationships, emotional and physical safety, and a connection with the community (Gambone, Klem, \& Connell, 2002). These findings are also consistent with strategies identified in Schusler and Krasny (2010), specifically creating safe spaces, building respectful and trusting relationships, and connecting youth with their community. Further, this evaluation suggests the potential for environmental service to serve as a context for positive youth development.

\section{Implications for Trail Guards and Other Youth Development Professionals}

This evaluation highlights the importance of positive adult role models, providing a safe and caring environment, and community involvement in youth development programs. These appear to be important characteristics for inclusion in programs aiming toward positive youth development. For Trail Guards, the program leader is primarily serving as this role model for Trail Guards participants. Through the qualitative findings, youth appear to be developing a strong sense of commitment and loyalty to Trail Guards, as well as a sense of responsibility and accountability. It seems Trail Guards could capitalize on this loyalty, commitment, and sense of responsibility through a more deliberate incorporation of a youth leadership component. By doing so, desirable youth development outcomes could be achieved, such as a sense of belonging, autonomy, competence (Benard, 2004). Further, this would provide an avenue for youth leaders to contribute toward program sustainability, as youth leadership benefits an organization by "stimulating greater ownership of the program by the youth and ownership by the community; growing potential new leaders and workers who come from the communities they serve; and using their youth as positive role models for other youth" (Paul, \& Lefkovitz, 2006, p. 5). 
A second implication relates to the role of incentives. Currently, Trail Guards uses a point/reward system, where participants can earn points through their work and use them toward outdoor adventure trips. This is consistent with the strategy of "expanding horizons through novel experiences" in the Schusler and Krasny (2010) framework. While the use of special field trips is supported in the literature as being an appropriate and effective incentive for engaging elementary and middle school children in out-of-school time programs (McAllister, 1990; Weiss, 2006), research has shown leadership opportunities, internships and other job preparation activities, and financial incentives to be effective in engaging high school youth (National Academy of Sciences, 2004; New Jersey After 3, 2007). Thus, it may be worth considering incorporating a youth leadership component into the point/reward system for the older youth participants, where youth through long-term, on-going participation earn leadership roles in Trail Guards. Doing so will better align with research-based recommendations for using incentives sparingly and diminishing their use as participants' intrinsic enjoyment of program components retains their interest and involvement (Pearce, \& Larson, 2006).

Acknowledgments: The authors wish to acknowledge the environmental education graduate students at (blank for blind review), for their contribution to the planning of this evaluation and their data collection and analysis efforts.

\section{References}

Benard, B. (2004). Resiliency: What we have learned. San Francisco: West ED.

Catalano, M., Berglund, L., Ryan, J., Lonczak, H., \& Hawkins, D. (2004). Positive youth development in the United States: Research findings on evaluations of positive youth development programs. The ANNALS of the American Academy of Political and Social Science, 591, 98-124.

Ernst, J. (2005). A formative evaluation of the Prairie Science Class. Journal of Interpretation Research, 10(1), 9-30.

Gambone, M., Klem, A., \& Connell, J. (2002). Finding out what matters for youth: Testing key links in a community action framework for youth development. Philadelphia: Youth Development Strategies, Inc., and Institute for Research and Reform in Education.

McAllister, C. (1990). The process of providing incentives. Journal of Instructional Psychology, 17(3).

Melchior, A., \& Bailis, L. (2004). Earth Force 2003-2004 program evaluation. Waltham, MA: Center for Youth and Communities: Brandeis University.

National Academy of Sciences. (2004). Community programs to promote youth development. Retrieved October 1, 2010, at: http://www.bocyf.org/youth development brief.pdf. Washington, DC. National Academies Press.

New Jersey After 3, Inc. (2007). Promising afterschool practices: A showcase of innovative, creative, and successful afterschool programs. New Brunswick, NJ: Author. 
Patton, M. (2002). Qualitative research and evaluation methods. Thousand Oaks, CA: Sage Publishing.

Paul, A., \& Lefkovitz, B. (2006). Engaging youth: A how-to guide for creating opportunities for young people to participate, lead and succeed. Sacramento, CA: Sierra Health Foundation.

Pearce, N., \& Larson, R. (2006). How teens become engaged in youth development programs: The process of motivational change in a civic activism organization. Applied Developmental Science, 10(3), 121-131.

Schusler, T., \& Krasny, M. (2010). Environmental action as context for youth development. Journal of Environmental Education, 41(4), 208-223.

Weiss, H. (2006). Summer success: Challenges and strategies for creating quality academically focused summer programs, issues and opportunities in out-of-school time evaluation, No. 9. Cambridge, MA: Harvard Youth Research Project.

(C) Copyright of Journal of Youth Development Bridging Research and Practice. Content may not be copied or emailed to multiple sites or posted to a listserv without copyright holder's express written permission. Contact Editor at: patricia.dawson@oregonstate.edu for details. However, users may print, download or email articles for individual use. ISSN 2325-4009 (Print); ISSN 2325-4017 (Online) 


\section{Appendices \\ Past Participant Questionnaire}

Thank you for participating in the evaluation of the Trail Guards program, and we sincerely appreciate your time and effort! Please return this questionnaire by Saturday, April $14^{\text {th }}$, using the stamped/pre-addressed envelope provided.

1. In which age range do you belong? Circle one.
Under 18
$18-21$
$22-24$
$25-28$
29 and older

2. In what way did you participate in Trail Guards? Check all that apply _ Saturday Mornings ___ Outdoor Adventure Rewards (Trips) __ "My Room" Project

_ Other. Please list.

3. Approximately how long did you participate in Trail Guards as a youth? years

4. Are you still involved with Trail Guards? Circle one. YES NO

If yes, in what way?

5. What did you gain from participation in Crow River Trail Guards?

6. What were the most valuable things you learned from participation in the Trail Guards program? Did you apply what you learned through Trail Guards in other aspects of your life? If so, in what ways?

7. Has your life changed because of participation in Crow River Trail Guards? If so, how?

\begin{tabular}{|c|c|c|c|c|c|}
\hline $\begin{array}{l}\text { As a result of my participation in the Trail Guards } \\
\text { program.... }\end{array}$ & $\begin{array}{l}\text { Strongly } \\
\text { disagree }\end{array}$ & Disagree & Neither & Agree & $\begin{array}{c}\text { Strongly } \\
\text { agree }\end{array}$ \\
\hline 1. I feel a personal connection to nature. & 0 & 0 & 0 & 0 & 0 \\
\hline 2. I feel an attachment to Crow River Nature Park. & 0 & 0 & 0 & 0 & 0 \\
\hline 3. I learned practical skills in trail maintenance. & 0 & 0 & 0 & 0 & 0 \\
\hline $\begin{array}{l}\text { 4. I am confident in my ability to identify my personal } \\
\text { skills. }\end{array}$ & 0 & 0 & 0 & 0 & 0 \\
\hline 5. I feel others truly appreciate me for who I am. & 0 & 0 & 0 & 0 & 0 \\
\hline 6. I developed an ability to accomplish tasks. & 0 & 0 & 0 & 0 & 0 \\
\hline 7. I developed a sense of belonging. & 0 & 0 & 0 & 0 & 0 \\
\hline 8. I learned how to cooperate as a part of team. & 0 & 0 & 0 & 0 & 0 \\
\hline 9. I developed problem-solving skills. & $\mathrm{O}$ & $\mathrm{O}$ & 0 & 0 & 0 \\
\hline 10. I feel I can play an important role in the community. & 0 & 0 & 0 & 0 & $\mathrm{O}$ \\
\hline 11. I feel appreciative of the environment. & 0 & 0 & 0 & 0 & 0 \\
\hline $\begin{array}{l}\text { 12. I am connected to the natural spaces in my } \\
\text { community. }\end{array}$ & 0 & 0 & 0 & 0 & 0 \\
\hline $\begin{array}{l}\text { 13. I believe taking care of the Crow River Nature Park is } \\
\text { important. }\end{array}$ & 0 & 0 & 0 & 0 & 0 \\
\hline 14. I am able to identify my personal strengths. & 0 & 0 & 0 & 0 & 0 \\
\hline $\begin{array}{l}\text { 15. I feel I have made a valuable contribution to the work } \\
\text { of Trail Guards. }\end{array}$ & 0 & 0 & 0 & 0 & 0 \\
\hline $\begin{array}{l}\text { 16. I gained an ability to participate in meaningful } \\
\text { relationships with other people. }\end{array}$ & 0 & 0 & 0 & 0 & 0 \\
\hline $\begin{array}{l}\text { 17. I felt accepted as a member of the Crow River Trail } \\
\text { Guards. }\end{array}$ & 0 & 0 & 0 & 0 & 0 \\
\hline $\begin{array}{l}\text { 18. I am able to provide solutions to challenging } \\
\text { situations. }\end{array}$ & 0 & 0 & 0 & 0 & 0 \\
\hline 19. I am a responsible community member. & 0 & 0 & 0 & 0 & 0 \\
\hline 20. I am interested in learning about the environment. & 0 & 0 & 0 & 0 & 0 \\
\hline $\begin{array}{l}\text { 21. I have developed a relationship with the people in my } \\
\text { community. }\end{array}$ & 0 & 0 & 0 & 0 & 0 \\
\hline $\begin{array}{l}\text { 22. I believe trail maintenance is very important to the } \\
\text { conservation of natural areas. }\end{array}$ & 0 & 0 & 0 & 0 & 0 \\
\hline $\begin{array}{l}\text { 23. I feel others truly valued my contributions to Trail } \\
\text { Guards. }\end{array}$ & 0 & 0 & 0 & 0 & 0 \\
\hline $\begin{array}{l}\text { 24. I am able to cooperate with a team to work toward a } \\
\text { common goal. }\end{array}$ & 0 & 0 & 0 & 0 & 0 \\
\hline
\end{tabular}




\section{Parent Questionnaire}

Thank you for participating in the evaluation of the Trail Guards program, and we sincerely appreciate your time and effort! Please return this questionnaire by Saturday, April 14th, using the stamped/preaddressed envelope provided.

1. Throughout the summer season, about how many times per month did/does your child/children attend the Saturday morning Trail Guards program?

$\square 4$ Saturdays a month

$\square 3$ Saturdays a month

$\square 2$ Saturdays a month

1 Saturday a month

Less than 1 Saturday a month

2. Has your child/children participate in the outdoor adventure trips earned through the point/reward system?

$\square$ yes $\quad \square$ no

3. When your child/children started participating in Trail Guards, what was his/her primary motivation for participating?

$\square$ to be with friends

$\square$ to maintain the park

$\square$ to be outside

$\square$ to make new friends

$\square$ needed something to do for the summer

$\square$ educational opportunities

$\square$ food and snacks

$\square$ to participate in Outdoor Adventure Rewards program

$\square$ other, please specify:

4. What is your child's/children's primary motivation for continued participation in the Trail Guards program?

$\square$ to be with friends

$\square$ to maintain the park

$\square$ to be outside

$\square$ to make new friends

$\square$ need something to do for the summer

$\square$ educational opportunities

$\square$ food and snacks

$\square$ to participate in Outdoor Adventure Rewards program

$\square$ other, please specify:

5. Does your child/children go to the Crow River Nature Park outside of Trail Guard Saturday mornings?
often
sometimes
rarely
never

6. When your child/children participates in Trail Guards, does he/she feel valued by the community for his/her contributions?

$\square$ not at all $\quad \square$ somewhat $\quad \square$ very 
7. Please rate your level of agreement with each of the following statements by marking one response for each item.

\begin{tabular}{|c|c|c|c|c|c|}
\hline $\begin{array}{l}\text { As a result of participating in the Trail Guards } \\
\text { program, my child (children)...... }\end{array}$ & $\begin{array}{l}\text { Strongly } \\
\text { Agree }\end{array}$ & Agree & Neither & Disagree & $\begin{array}{l}\text { Strongly } \\
\text { Disagree }\end{array}$ \\
\hline has an interest in the natural world & $\mathrm{O}$ & $\mathrm{O}$ & $\mathrm{O}$ & $\mathrm{O}$ & $\mathrm{O}$ \\
\hline has an appreciation for the natural world & 0 & 0 & O & $\mathrm{O}$ & 0 \\
\hline has a connection to the natural world & $\mathrm{O}$ & 0 & $\mathrm{O}$ & $\mathrm{O}$ & $\mathrm{O}$ \\
\hline has trail maintenance skills & $\mathrm{O}$ & 0 & $\mathrm{O}$ & $\mathrm{O}$ & $\mathrm{O}$ \\
\hline $\begin{array}{l}\text { feels a responsibility towards the Crow River } \\
\text { Nature Park }\end{array}$ & $\mathrm{O}$ & 0 & $\mathrm{O}$ & $\mathrm{O}$ & $\mathrm{O}$ \\
\hline wants to protect the Crow River Nature Park & $\mathrm{O}$ & 0 & $\mathrm{O}$ & $\mathrm{O}$ & $\mathrm{O}$ \\
\hline is aware of his/her personal strengths & 0 & $\mathrm{O}$ & 0 & $\mathrm{O}$ & $\mathrm{O}$ \\
\hline is aware of his/her personal skills & 0 & 0 & 0 & $\mathrm{O}$ & 0 \\
\hline values who he/she is & 0 & 0 & 0 & $\mathrm{O}$ & 0 \\
\hline $\begin{array}{l}\text { has a belief in his/her ability to accomplish a } \\
\text { task }\end{array}$ & 0 & 0 & 0 & 0 & 0 \\
\hline $\begin{array}{l}\text { has a positive attitude toward contributing to } \\
\text { the Paynesville community }\end{array}$ & $\mathrm{O}$ & 0 & $\mathrm{O}$ & $\mathrm{O}$ & $\mathrm{O}$ \\
\hline $\begin{array}{l}\text { feels able to successfully participate in social } \\
\text { settings }\end{array}$ & $\mathrm{O}$ & 0 & $\mathrm{O}$ & $\mathrm{O}$ & 0 \\
\hline $\begin{array}{l}\text { has the skills to successfully participate in } \\
\text { social settings }\end{array}$ & 0 & 0 & 0 & 0 & 0 \\
\hline can work successfully in a team & 0 & 0 & $\mathrm{O}$ & 0 & 0 \\
\hline can cooperate with others & 0 & 0 & 0 & 0 & $\mathrm{O}$ \\
\hline has strong problem-solving skills & 0 & 0 & 0 & 0 & 0 \\
\hline $\begin{array}{l}\text { identifies strongly with the Crow River Nature } \\
\text { Park }\end{array}$ & 0 & 0 & 0 & $\mathrm{O}$ & 0 \\
\hline $\begin{array}{l}\text { has a sense of responsibility towards the } \\
\text { Paynesville community }\end{array}$ & 0 & $\mathrm{O}$ & 0 & 0 & $\mathrm{O}$ \\
\hline
\end{tabular}

12. In your opinion, how have you seen your child/children change, if at all, through his/her participation in the Trail Guards program?

13. How have your child's/children's experiences in the Trail Guards program impacted his/her current life, activities, or decisions?

14. What do you feel is the most important thing your child has gained through participating in Trail Guards? 


\section{Current Participant Self-Report}

\begin{tabular}{|c|c|c|c|c|c|}
\hline $\begin{array}{l}\text { Please respond as honestly as possible. There are no right or } \\
\text { wrong answers! Answer based on what is true for you, not how } \\
\text { you think others might feel. }\end{array}$ & $\begin{array}{l}\text { Strongly } \\
\text { Agree }\end{array}$ & Agree & $\begin{array}{l}\text { Not } D \\
\text { Certain }\end{array}$ & Disagree & $\begin{array}{l}\text { Strongly } \\
\text { Disagree }\end{array}$ \\
\hline I am aware of my own skills and abilities. & SA & A & NC & $\mathrm{D}$ & SD \\
\hline I know what I am good at (my strengths). & SA & A & NC & $\mathrm{D}$ & SD \\
\hline $\begin{array}{l}\text { I am aware of what skills and strengths others have noticed of } \\
\text { me. }\end{array}$ & SA & A & NC & $\mathrm{D}$ & SD \\
\hline I feel others respect me for who I am or what I do. & SA & A & NC & $\mathrm{D}$ & SD \\
\hline I feel others appreciate me for who I am or what I do. & SA & A & NC & $\mathrm{D}$ & SD \\
\hline I feel worthy of being respected. & SA & A & NC & $\mathrm{D}$ & SD \\
\hline I feel I have value as a person. & SA & A & NC & $\mathrm{D}$ & SD \\
\hline I feel I have skills to offer when there is work to be done. & SA & A & NC & $\mathrm{D}$ & SD \\
\hline I feel I can accomplish a task given to me. & SA & A & NC & $\mathrm{D}$ & SD \\
\hline $\begin{array}{l}\text { I know how to act and what to say when I'm with someone } \\
\text { else. }\end{array}$ & SA & A & NC & $\mathrm{D}$ & SD \\
\hline $\begin{array}{l}\text { I know how to act and what to say when I'm with others in a } \\
\text { group. }\end{array}$ & SA & A & NC & $\mathrm{D}$ & SD \\
\hline I know how to get along with others. & $\mathrm{SA}$ & A & NC & $\mathrm{D}$ & SD \\
\hline Others accept me for who I am. & SA & A & NC & $\mathrm{D}$ & SD \\
\hline $\begin{array}{l}\text { I feel I belong when I am with others in a group (I feel part of } \\
\text { the group). }\end{array}$ & SA & A & NC & $\mathrm{D}$ & SD \\
\hline I know how to work with others to accomplish a task. & SA & A & NC & $\mathrm{D}$ & SD \\
\hline $\begin{array}{l}\text { I cooperate with others when we are working together to get a } \\
\text { job done. }\end{array}$ & SA & A & NC & $\mathrm{D}$ & SD \\
\hline $\begin{array}{l}\text { I know how to work with others to get a job done, even if I } \\
\text { don't particularly like who I am working with. }\end{array}$ & SA & A & NC & $\mathrm{D}$ & SD \\
\hline I can make a difference in my community. & SA & A & NC & $\mathrm{D}$ & SD \\
\hline I feel it is my responsibility to help make my community better. & SA & A & NC & $\mathrm{D}$ & SD \\
\hline $\begin{array}{l}\text { Helping solve community problems is something everyone } \\
\text { should do. }\end{array}$ & SA & A & NC & $\mathrm{D}$ & SD \\
\hline I plan to volunteer in community throughout my life. & SA & A & NC & $\mathrm{D}$ & SD \\
\hline $\begin{array}{l}\text { I feel it is important to contribute to your community in } \\
\text { whatever ways you can. }\end{array}$ & SA & A & NC & $\mathrm{D}$ & SD \\
\hline
\end{tabular}

